\title{
MEKANISME INFEKSI VIBRIO PADA RESEPTOR IKAN KERAPU TIKUS Cromileptes altivelis
}

\section{THE MECHANISM OF VIBRIO INFECTION TO GROUPER RESEPTOR Cromileptes altivelis}

\author{
Uun Yanuhar
}

Fakultas Perikanan dan Ilmu Kelautan, Universitas Brawijaya, Malang, Indonesia

Jl. Veteran, Malang 65145

Telp. 0341-553512

\begin{abstract}
One of the most favourite fish that farmer fish cultivated because its high economic value was gouper ( $C$. altivelis). The obstacle in cultivation system was caused by Vibrio algynolitycus. Vibrio angullarum, Vibrio parahaemolyticus. Vibrio harveyi infection. Many deseases that attacked to the grouper was caused by the role of pathogen specific as a ligan and its reseptor.

The aim of these study was to improve and to know the role of reseptor in vibriosis mechanism with tested spesific reseptor protein of grouper Cromileptes altivelis. These study used experimental and descriptive methode with identified of grouper reseptor, Hemaglutinin test and observation use electron microscope.

These study result showed that reseptor protein of $C$. altivelis was found in its eyes. These showed spesivity and reactivity to the vibriosis specific epitop.
\end{abstract}

Keywords : reseptor, grouper, vibriosis

\section{Pendahuluan}

Sebagai komoditas eksport kedua setelah udang, ikan kerapu bebek atau kerapu tikus (C. altivelis) saat ini merupakan salah satu jenis ikan yang sangat diminati oleh petani ikan untuk dibudidayakan karena mempunyai nilai ekonomis tinggi, akan tetapi dalam perkembangan budidaya ikan kerapu ini masih dihadapkan pada beberapa masalah, diantaranya adalah penyakit yang disebabkan oleh mikroba yaitu bakteri seperti $V$. parahaemolyticus, $V$. alginolyticus, V.cholerae, $V$. anguilarum, $V$.harveyi dan $V$. fulnivicus). Pada juvenil ikan kerapu tikus dengan rata-rata berat 9,91 gram15,40 gram dan panjang 6-10 cm rentan terhadap infeksi mikroba. Kematian masal yang disebabkan oleh penyakit infeksi tersebut mencapai 90-100\% (rata-rata 93,3\%) selama 21 hari. Kematian ikan kerapu tidak hanya terjadi pada stadia larva dan juvenile secara masal tetapi juga pada induk kerapu yang dipelihara dalam bak induk hingga mencapai $40 \%$ (Mahardika \& Zafran, 2004). Baru-baru ini ditemukan juga spesies $V$. vluvialis pada ikan kerapu tikus (Istiqomah et al., 2006). Kerugian pada industri budidaya perikanan air laut dan tawar secara serius juga disebabkan oleh spesies Vibrio yang mengakibatkan kematian ikan budidaya pada tingkat benih mencapai 99\% (Wang et al., 1998) dan (Denkin \& Nelson, 2004).
Hasil penelitian pendahuluan terhadap infeksi V. alginoluticus, V. parahaemolyticua, V. anguilarum dan V. harveyi dengan cara infeksi secara injeksi intramuscular dan juga secara perendaman menunjukkan bahwa kepadatan bakteri hingga $10^{8-10} \mathrm{CFU} / \mathrm{ml}$ pada ikan kerapu pasca infeksi terjadi kematian ikan pada jam ke- 8 dengan imunisasi, dengan gejala terjadinya luka borok menganga, dan perubahan perilaku, bergerak lamban, keseimbangan terganggu, yaitu berputar-putar (whirling) dan nafsu makan berkurang, akan tetapi ikan pada perlakuan perendaman ikan bertahan hingga 24 jam-96jam. Imunisasi secara intraperitoneal menunjukkan bahwa dengan imunisasi bakteri $V$. alginolyticus $10^{10}$ menunjukkan kematian hingga 5 jam pertama pasca infeksi dengan perubahan warna morfologi ikan menjadi kegelapan, inflamasi, sampai abses pada bekas injeksi, timbul bercak merah pada pangkal sirip, timbul perdarahan pada insang dan mulut, perut menggelembung hingga terjadi kematian. Yanuhar ( 2008) sebelumnya juga menjelaskan dalam penelitiannya bahwa gejala infeksi pada ikan kerapu dengan menggunakan jenis bakteri lain seperti $V$. parahaemolyticus, V. anguilarum dan V.harvey, akan tetapi tingkat keganasan berdasarkan identifikasi dengan menggunakan uji haemaglutinasi, bakteri $V$. alginolyticus merupakan bakteri yang lebih virulen berdasarkan titer haemaglutinin yang telah 
diujikan dengan eritrosit ikan kerapu . Berdasarkan tingkat serangan bakteri telah ditemukan sebelumnya bahwa pathogenesis bakteri $V$. alginolyticus diperankan oleh peran dan fungsi dariprotein reseptor dan protein adhesion dari bakteri V. alginolyticus (Yanuhar, 2006), yaitu melibatkan peran reseptor spesifik pada permukaan sel (specific cell surface molecule) yang disebut sebagai reseptor adesi yang dapat digolongkan menjadi superfamili yaitu: immunoglobulin, cadherin, integrin dan selectin (Sudhakar \& Subramani, 2006).

\section{Materi dan Metode Penelitian}

Material dalam penelitian ini meliputi, isolat bakteri $V$. alginolyticus, $V$. anguilarum, $V$. parahaemolyticus, $V$. harveyi dan ikan kerapu tikus dengan pemeriksaan scanning laser mikroskop.

Kultur Vibrio spp.

Dalam penelitian ini, bakteri yang digunakan adalah V.alginolyticus, V.anguilarum, V.harveyi dan V.parahaemolyticus. Bakteri ini diperoleh dari BBAP Jepara dalam bentuk agar miring. Kemudian dilakukan kultur di Laboratorium Mikrobiologi Universitas Brawijaya. Kultur ini menggunakan media TCBS (uji konfirmasi), media BHI (uji protein) dan LB (uji DNA). Kultur dilakukan diawali dengan Vibrio ditanam pada media TCBS selama 24 jam pada suhu $24^{\circ} \mathrm{C}$. Hasil dari biakan diambil dengan cara kerokan yang sebelumnya dituang PBS steril pH 7,4 secukupnya. Suspensi bakteri kemudian dimasukkan dalam botol yang berisi $500 \mathrm{ml}$ Brain Heart Infussion Broth (BHI), kemudian digoyang kuat selama 30 menit pada penangas air suhu $37^{\circ} \mathrm{C}$. selanjutnya suspensi bakteri sebanyak $250 \mathrm{ml}$ dimasukkan dalam setiap botol yang mengandung media LB. Selanjutnya dilakukan pengeraman suhu $37^{\circ} \mathrm{C}$ selama 2 × 24 jam.

Test Haemagglutinasi

Petunjuk penelitian seperti dilakukan oleh Ehara dengan modifikasi (Sumarno et al., 1991 dan Winarsih S., et al., 1998). Hasil koleksi pili tersebut dilakukan SDS-PAGE. Gel dipotong lurus pada berat molekul yang diinginkan dan potongan pita tersebut dikumpulkan dan dimasukkan dalam tabung membran dialisa memakai cairan penyangga elektroforesis running buffer. Selanjutnya dilakukan elektroelusi menggunakan alat elektroforesis horisontal aliran $125 \mathrm{mV}$ selama 25 menit. Hasil elektroforesis dilakukan dialisa dengan cairan penyangga PBS 2 liter $\mathrm{pH} 7,4$ selama 1 x 24 jam dan 2 liter aquades selama 1 x 24 jam. Cairan dialisat yang berasal dari potongan pita SDS-Page tersebut dilakukan uji hemaglutinasi.

Sodium Dodecyl Sulfate Polyacrylamid Gel Electrophoresis (SDS-Page)

Monitoring berat molekul dikerjakan menggunakan SDS-Page metode Laemmli (1970). Sampel protein dipanaskan $100^{\circ} \mathrm{C}$ selama 5 menit dalam larutan penyangga yang mengandung $5 \mathrm{mM}$ Tris HCL pH 6,8, 5\% 2mercapto ethanol, 2,5\% w/v sodium dodecyl sulfate, $10 \% \mathrm{v} / \mathrm{v}$ glycerol dengan warna pelacak bromophenol blue. Dipilih 12,5\% mini slab gel dengan tracking gel $4 \%$. Voltase yang digunakan $125 \mathrm{mV}$. Sebagai bahan warna adalah coomassie brilliant blue dan molekul standar sigma low range marker.

Teknik pemeriksaan Immunokimia

Antigen dan protein reseptor dari organ ikan kerapu C. altivelis sebanyak $20 \mu \mathrm{l}$ diencerkan dalam sodium azida $\left(\mathrm{NaN}_{3}\right) \quad 1 \%$ (1:4). Diteteskan pada membran nitroselulosa yang telah dibasahi PBS yang terangkai pada alat Dot Blotter. Didegas selama 30 menit. Membran di-blocking dengan PBS-Skim 5\% selama 1 jam. Dicuci dengan PBS-Tween $0,05 \%$ selama $3 \times 3$ menit. Inkubasi dengan antibodi primer (IgM) yang telah diencerkan dalam PBS-Skim 5\% (1:200) selama 2 jam sambil digoyang. Dicuci $3 \times 3$ menit dengan PBS-Tween. Diinkubasi dengan antibody sekunder Anti IgM Alkaline Phospatase (AP) Conjugated dalam TBS (1:2500) selama 1 jam sambil digoyang. Dicuci dengan PBS-Tween $0,05 \%$ selama $3 \times 3$ menit, dilanjutkan dengan iinkubasi dalam substrat Western Blue (dalam ruang gelap) selama 30 menit. Reaksi dihentikan dengan penambahan aquades. Membran dikeringkan dan diamati ada tidaknya noda berwarna biru gelap.

\section{Hasil dan Pembahasan}

Tes Haemaglutinasi Vibrio spp.

Hasil penelitian terhadap tes haemaglutinasi pada $V$. alginolyticus, $V$. parahaemolyticus, $V$. anguilarum dan $V$. harveyi menunjukkan (Tabel 1) bahwa bakteri $V$. alginolyticus mempunyai titer haemaglutinin yang lebih tinggi konsentrasinya daripada $V$. anguilarum, $V$. parahaemolyticus dan $V$. harveyi.

Test Haemaglutinasi

Uji aglutinasi $V$. alginolyticus isolat Vibrio spp. ditentukan dari beberapa isolat yang mempunyai titer aglutinasi positif dari 
Tabel . 1 Hasil uji Hemaglutinasi Vibrio spp. secara bertingkat terhadap eritrosit ikan kerapu tikus C. altivelis

\begin{tabular}{|l|cccccccccccc|c|}
\hline Sumur/ materi & 1 & 2 & 3 & 4 & 5 & 6 & 7 & 8 & 9 & 10 & 11 & 12 \\
& $1 / 2$ & $1 / 4$ & $1 / 8$ & $1 / 16$ & $1 / 32$ & $1 / 64$ & $1 / 128$ & $1 / 256$ & $1 / 512$ & $1 / 1024$ & $1 / 2048$ & $\mathrm{~K}$ \\
\hline V. alginolyticus & + & + & + & + & + & + & + & + & + & - & - & - \\
V. anguilarum & + & + & + & + & + & + & + & - & - & - & - & - \\
V. parahaemolyticus & + & + & + & + & + & - & - & - & - & - & - & - \\
V. harveyi & + & + & - & - & - & - & - & - & - & - & - & - \\
Kontrol & - & - & - & - & - & - & - & - & - & - & - & - \\
\hline
\end{tabular}

Keterangan :

V. alginolyticus titer positif haemaglutinin (1/512)

$V$. anguilarum titer positif haemaglutinin ( )

V. parahaemolyticus titer positif haemaglutinin ( )

$V$. harveyi titer positif haemaglutinin ( )

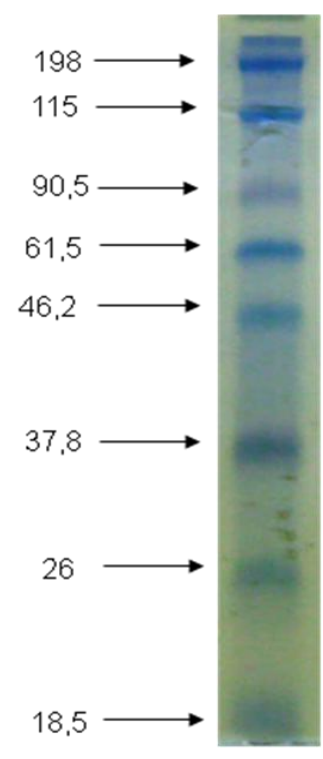

A

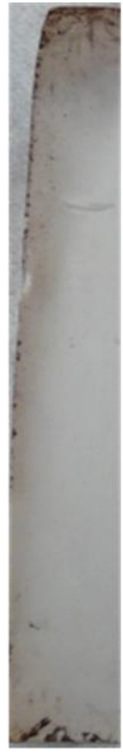

93,4

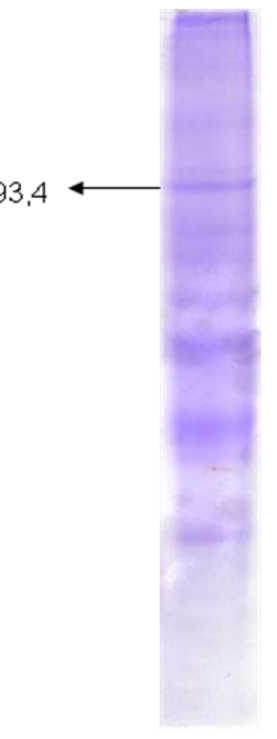

C

Gambar 1. Hasil elektroforesis SDS-Page protein reseptor dari organ mata C.altivelis dengan pewarnaan commassie brillian blue R-250

Keterangan :

Lajur A : Protein perunut Low marker merk Sigma

Lajur B : pita protein reseptor organ mata C. altivelis berat molekul 93,4 kDa memberikan reaksi silang positif

Lajur C : pita protein reseptor berat 93,4 kDa dilakukan uji untuk western blotting

konsentrasi tertinggi hingga terendah terhadap eritrosit ikan kerapu tikus C.altivelis .

Berdasarkan hasil penelitian terhadap uji aglutinasi menunjukkan bahwa whole cell bakteria memberikan titer positif haemaglutinin hingga pengenceran $1 / 512$ untuk V.alginolyticus, berikutnya $V$. anguilarum, $V$. parahaemolyticus dan $V$. harveyi (Tabel 1).
Hasil uji haemaglutinin berdasarkan titer pengenceran konsentrasi bakteri terhadap eritrosit ikan kerapu menunjukkan bahwa titer tertinggi dari masing-masing bakteri mempunyai protein adhesion yakni haemaglutinin yang berarti mampu mengaglutinasi eritrosit ikan kerapu.

Elektroforesis SDS-PAGE Protein Reseptor Grouper 

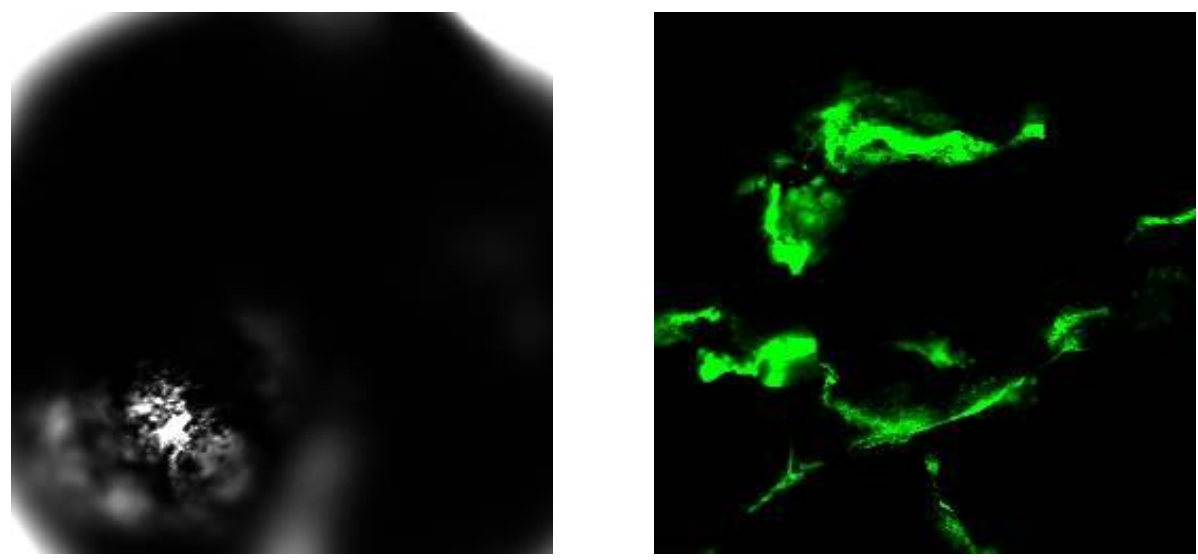

Gambar 2. Ekspresi Reseptor Mata normal dan terinfeksi V. alginolyticus dengan pemeriksaan CLSM

Hasil penelitian terhadap berat molekul reseptor organ mata ikan kerapu tikus $\mathrm{C}$. altivelis dengan SDS-Page adalah 133,$7 ; 115,8$ $\mathrm{kDa} ; 105,3 \mathrm{kda}$; 93,4 kDa; 86,9 kDa; 79,0 kDa; 68,4 kDa; 59,2 kDa; 52,6 kDA; 48,9 kDa; 41,4 $\mathrm{kDa} ; 33,3 \mathrm{kDa} ; 26$,2 kDa (Gambar 2c). Hasil pita protein reseptor yang telah diuji adalah berat molekul 93,4 kDa yang sudah dilakukan uji reaksi silang terhadap serum ikan kerapu tikus C. altivelis, dengan pemeriksaan imunokimia memberikan reaksi silang positif .

Berdasarkan hasil elektroforesis protein reseptor organ mata ikan kerapu $C$. altivelis yang diisolasi dari organ sebagai reseptor protein terhadap adesi $V$. alginolyticus menunjukkan gambaran pita protein yang berbeda. Pada pengujian ini telah ditentukan bahwa berat molekul 93,4 kDa yang digunakan dengan pengujian imunokimia menggunakan teknik western blotting memberikan reaksi silang setelah dilakukan pengujian reseptor dengan protein adesi V.alginolyticus. Pengujian lebih lanjut perlu untuk $V$. anguilarum, $V$. parahaemolyticus, dan V.harveyi.

Pemeriksaan ekspresi reseptor mata terhadap infeksi Vibrio spp.

Hasil pengujian terhadap ekspresi reseptor protein mata terhadap perlekatan bakteri Vibrio spp. diantaranya adalah $\mathrm{V}$. alginolyticus terhadap menunjukkan bahwa ekspresi reseptor protein pada organ mata berbeda antara organ normal dan terinfeksi Vibrio. Gambaran hasil ekspresi reseptor protein mata terhadap perlekatan bakteri V.alginolyticus menunjukkan pola fluorescent yang kuat dibandingkan dengan yang normal tidak terinfeksi Vibrio (Gambar 2).

Mekanisme ekspresi reseptor protein mata ikan kerapu terhadap infeksi Vibrio spp (dalam hal ini $V$. alginolyticus) ditemukan sementara bahwa berat molekul 93,4 kDa memberikan reaksi silang positif dengan pemeriksaan imunokimia menggunakan antibodi primer poliklonal antibodi anti-IgM grouper, dan sekunder anti IgM grouper.

Berdasarkan hasil penelitian menunjukkan keempat bakteri V.alginolyticus, V.anguilarum, $V$. parahaemolyticus dan $V$. harveyi mempunyai titer haemaglutinin, haemaglutinin ini merupakan protein adhesion dari bakteri tersebut. Pada penelitian sebelumnya telah dilakukan pengujian haemagglutinin bahwa haemaglutinin yang ditemukan merupakan protein adhesion dan juga merupakan molekul glikoprotein, dimana glikoprotein juga ditemukan pada organ usus tepatnya sel epitel usus ikan kerapu tikus (Yanuhar, 2006). Glikoprotein dijelaskan Beachy (1981) berfungsi untuk migrasi seluler selama perkembangan dan wound healing, regulasi pertumbuhan sel dan deferensiasi yang juga berperan utama dalam trombosis. Glikoprotein ini juga berperan pada perlekatan bakteri terhadap permukaan mukosa yang merupakan step awal patogenesis dari hampir semua penyakit infeksi yang disebabkan oleh bakteri baik pada hewan maupun manusia. Mekanisme perlekatan terdiri dari ikatan adesi molekul dari permukaan bakteri (adhesin) dan membran sel host (reseptor).

\section{Kesimpulan}

Kesimpulan dari penelitian ini adalah bahwa protein mata C.altivelis dengan berat molekul 93,4 kDa memberikan reaksi silang terhadap protein adesin hemaglutinin V.alginolyticus. Reseptor organ ikan kerapu tikus berperan penting dalam mekanisme infeksi Vibrio spp. 
Karena keterbatasan poliklonal antibodi seperti reaksi silang, kuantitas yang terbatas, latar belakang reaksi yang tidak diinginkan dan kemampuan mendeskriminasi antigen pada tingkat epitop menjadikan penelitian ini untuk dilakukan lebih mendalam terhadap peran protein reseptor dan juga protein adhesinnya.

\section{Ucapan terima kasih}

Ucapan terimakasih kepada program Insentif Riset Dasar Tahun 2008 yang telah memberikan grant untuk penelitian pengembangan vaksin berbasis peptida reseptor ikan kerapu tikus C.altivelis yang mengenali antigen general untuk transgenik antibodi untuk benih unggul.

\section{Daftar Pustaka}

Mahardika, K .Zafran, 2004. Infeksi Iridovirus Pada JuvenilKerapu Bebek (Cromileptes altivelis) Di Karamba Jaring Apung. Balai Besar Riset Perikanan Budidaya Laut Gondol. Bali. Prosiding. Pengendalian Penyakit Pada Ikan Dan Udang berbasis Imunisasi Dan Biosecurity.

Istiqomah, I., Isnasetyo, A., Triyanto, Nitimulyo, K. H., Murjani, M., 2006, Pathogenicity of Vibrio fluvialis 24SK in Humpback Grouper. Journal of Fisheries Science. Vol III. No. 1. P. 17-24

Wang, X.H., Oon, H.L., Ho, G.W.P., Wong, W.S.F., Lim, T.M., Leung, K.Y. 1998. Internalization and cytotoxicity are importance virulence mechanisms in vibrio-fish epithelial cell interactions. Microbiology, 144, p. 2987-3002

Denkin, S.M., Nelson, D.R. 2004. Regulation of Vibrio anguilarum empA Metalloprotease Expression and Its Role in Virulence. Applied and Environmental Microbiology, July. p.4193-4204.

Yanuhar, U. 2008. The role of Haemagglutinin Protein as Adhesin Molecule of Fimbriae Vibrio alginolyticus That Recognized by Receptor Membrane Protein of Intestine Cromileptes altivelis Within Pathomechanism Infection of Vibriosis. Pressented on International Seminar Management Strategy on Animal Health and Production Control in the Anticipation of Global Warming for the Achievement of Millennium Developmental Goals, Surabaya

Yanuhar, U., Sukoso, Sumarno, Widodo, M. A. 2006. Kajian Molekuler Faktor Virulensi Bakteri Dalam Patomekanisme Infeksi Vibrio alginolyticus Pada Cromileptes altivelis. Pressented on Conference of Indonesian Aquaculture , 6-8 Juni 2006, Surabaya

Sudhakar, P., and Subramani, P., 2006, Review: Mechanism of Bacterial Pathogenesis and Targets for Vaccine Design. St. Peters's Chemical College, Tamil Nadu, India, P. 1-16

Sumarno, Noorhamdani, A.S., Samsul Islam, Sjoekoer M. Dzen, Ehara, M, dan Ichinose, Y. 1991. Purifikasi protein hambatan aglutinasi Vibrio cholerae El Tor T79-6. Majalah Kedok. Univ. Brawijaya.Malang

Winarsih, S., Sumarno, dan Roekistiningsih. 1998. Fungsi dan sifat immunogenitas protein haemagglutinin $32 \mathrm{kDa}$ dan 20 kDa pada Helicobacter Pylori. Majalah Kedokteran Universitas Brawijaya Malang 8:11-14

Beachy E.H. 1981.Bacterial adherence: adhesinreceptor intewractions mediating the attachment of bacteria to mucosal surface. Journal Infect Diseases, Mar; 143 (3): 325-45. 